\title{
DÍVIDA PÚBLICA E RESPONSABILIDADE FISCAL
}

Licurgo Mourão

Doutor em Direito Econômico, Financeiro e Tributário pela Universidade de São Paulo (USP), com extensões universitárias na Hong Kong University, na California Western School of Law, na Université Paris 1 Pantheon-Sorbonne e na The George Washington University. Mestre em Direito Econômico pela Universidade Federal da Paraíba (UFPB). Pós-graduado em Direito Administrativo, Contabilidade Pública e

Controladoria Governamental pela Universidade Federal de Pernambuco (UFPE). Conselheiro substituto do Tribunal de Contas do Estado de Minas Gerais (TCEMG).

Ariane Shermam

Mestre em Direito Administrativo pela Universidade Federal de Minas Gerais (UFMG-2016). Bacharel em Direito pela mesma instituição (2012).

Autora de trabalhos acadêmicos na área de Direito Público. Membro da Comissão de Direito Administrativo da OAB/MG (2018).

\section{SUMÁRIO}

1. Breves antecedentes históricos - 2. Dívida pública e limites legais para o endividamento dos entes da Federação - 3. Regras sobre a dívida pública na Lei de Responsabilidade Fiscal - 4. Dívida pública e política econômica: os desafios da realidade brasileira - 5. Da interface entre planejamento estatal, metas fiscais e dívida pública - 6. Notas sobre o projeto de lei complementar para a limitação da dívida pública da União - Referências. 


\section{BREVES ANTECEDENTES HISTÓRICOS}

O conceito tradicional de dívida pública abrange os empréstimos tomados no mercado financeiro, interno ou externo, mediante contratos assinados com bancos e instituições financeiras ou por meio da oferta de títulos públicos. Nessa perspectiva, a dívida pública versa sobre as obrigações financeiras assumidas pelo Estado visando a suprir o caixa ou a fazer frente a investimentos.

Para Aliomar Baleeiro, a faculdade de contrair dívidas como meio de realização dos fins do Estado integra o caráter geral do processo econômico de repartição do custo de funcionamento do governo e, ao mesmo tempo, de redistribuição da renda nacional, ambos peculiares a toda a atividade financeira. ${ }^{1}$

$\mathrm{Na}$ tradição histórica, que remonta à Antiguidade, perpassa a Idade Média e chega à Idade Moderna, observou-se a confusão inicial entre o tesouro do governo e as riquezas dos governantes. Porém, já em Roma, fez-se distinção entre o fisco ("necessidades do imperador") e o erário ("necessidades do império"). ${ }^{2}$

O Brasil, por sua vez, antes de se tornar uma nação independente, não possuía dívida pública no sentido técnico do termo, embora seus governantes, nos diversos níveis administrativos, já contraíssem empréstimos desde o século XVI. ${ }^{3}$

No decorrer da história, a prática de contrair empréstimos - principalmente os internacionais, visando ao financiamento de empreitadas muitas vezes mal planejadas - adquiriu contornos de habitualidade e se tornou especialmente corriqueira no século XIX, na transição entre a dependência da metrópole e a recém-adquirida independência da jovem nação.

Não foi muito diferente durante os anos iniciais da República, quando a dívida externa continuou se expandindo, com duas finalidades precípuas: aparelhamento do Estado em seus serviços essenciais e aportes no caixa do Tesouro, haja vista a ineficiência na tributação e a escassez de capitais no mercado interno. ${ }^{4}$ Somaram-se a tal cenário desfavorável às contas públicas nacionais a dependência da exportação de produtos primários para o mercado externo, que se perpe-

1 BALEEIRO, Aliomar. Uma introdução à ciência das finanças. 19. ed. revista e atualizada por Hugo de Brito Machado Segundo. Rio de Janeiro: Forense, 2015. p. 599.

2 OLIVEIRA, Regis Fernandes de. Curso de direito financeiro. 7. ed. rev. atual. e ampl. São Paulo: Editora Revista dos Tribunais, 2015. p. 986.

3 BALEEIRO, Aliomar. Uma introdução à ciência das finanças. 19. ed. revista e atualizada por Hugo de Brito Machado Segundo. Rio de Janeiro: Forense, 2015. p. 588.

4 BALEEIRO, Aliomar. Uma introdução à ciência das finanças. 19. ed. revista e atualizada por Hugo de Brito Machado Segundo. Rio de Janeiro: Forense, 2015. p. 591. 
tua até os dias atuais, bem como o atrelamento do câmbio às flutuações do mercado internacional.

Necessário enfatizar, nesse contexto, que, desde há muito, os estudiosos das finanças públicas apontam para o caráter intergeracional que a dívida pode assumir, pois se contraem despesas no presente que onerarão as gerações vindouras. Assim, é recomendável que o Estado não contraia dívidas para custear gastos ordinários, cuja utilidade se esgote no momento de sua assunção, sem maior proveito para as gerações futuras. A dívida pública deve estar cingida, precipuamente, a investimentos (obras e bens duráveis), especialmente em infraestrutura, para a prestação de serviços públicos.

$\mathrm{Na}$ perspectiva teórica, há várias classificações para a dívida pública. Conforme esclarece Régis Fernandes de Oliveira, ${ }^{5}$ quanto à origem, a dívida pode ser externa, quando os credores são internacionais, ou interna, quando provém do mercado interno. Em relação à sua natureza, a dívida pode ser contratual ou mobiliária. No primeiro caso, decorre de contratos firmados com credores nacionais ou internacionais; na segunda hipótese, resulta da emissão de títulos, seja em leilão, seja de forma direta. Quanto à extensão da obrigação no tempo, a dívida pode ser consolidada ou flutuante. A dívida consolidada é de longo prazo (“amortização em prazo superior a doze meses”, nos termos do art. 29, I, da Lei n. 101/2000), relacionando-se com o investimento de capital de forma duradoura; a dívida flutuante, por sua vez, decorre de necessidades transitórias e deve ser liquidada no mesmo exercício, sendo, pois, de curto prazo (essa dívida só pode ser contraída a partir do décimo dia do exercício, devendo ser liquidada, com juros e outros encargos incidentes, até o dia 10 de dezembro de cada ano).

\section{DÍVIDA PÚBLICA E LIMITES LEGAIS PARA O ENDIVIDAMENTO DOS ENTES DA FEDERAÇÃO}

Vista em linhas gerais a classificação da dívida pública, passa-se ao percurso de construção de mecanismos e instrumentos para seu controle. Trata-se de medida essencial à manutenção de níveis recomendáveis de endividamento e propiciadoras de condições macroeconômicas equilibradas.

$\mathrm{Na}$ configuração constitucional e legislativa brasileira pós-redemocratização, o Senado Federal exerce papel de destaque no controle da dívida pública devido à sua competência privativa para estabelecer limites e condições para o endividamento dos entes federativos.

5 OLIVEIRA, Regis Fernandes de. Curso de direito financeiro. 7. ed. rev. atual. e ampl. São Paulo: Editora Revista dos Tribunais, 2015. p. 995. 
A posição de primazia do Senado no controle da dívida pública, em especial a dos entes subnacionais, se relaciona à sua missão precípua de equilibrar as forças estaduais, já que, composto por três representantes de cada Estado da federação, contrabalanceia o arranjo constitucional da Câmara dos Deputados, onde as cadeiras são distribuídas proporcionalmente ao tamanho da população de cada Estado. Assim, o Senado "tem o objetivo de controlar o endividamento dos Estados, zelando para que alguns não imponham ao resto do país o peso de um endividamento excessivo". ${ }^{6}$

Nesse aspecto, o controle do endividamento público visa a evitar problemas como inflação, redução da taxa de crescimento econômico de longo prazo, tributação excessiva das gerações vindouras e desequilíbrios regionais. ${ }^{7}$ Fica clara, desse modo, a relação direta entre contas públicas sustentáveis e condições macroeconômicas equilibradas, já assumindo como premissa que o planejamento estatal na área econômica é determinante para o setor público, mas apenas indicativo para o setor privado, como estipula o art. 174, caput, da Constituição de 1988.

Antes da edição da Lei Complementar n. 101/2000 (Lei de Responsabilidade Fiscal - LRF), o descontrole das contas públicas se revelava nos níveis elevadíssimos das dívidas de Estados e Municípios, muitos dos quais já estavam insolventes em meados da década de 90 do século passado. Era crucial naquele momento, como continua sendo até hoje, embora o cenário macroeconômico seja distinto, a adoção de mecanismos de limitação do endividamento público, o que foi efetuado por meio da renegociação e refinanciamento da dívida de Estados e Municípios ${ }^{8}$ e da redução da presença do Estado no setor financeiro, por meio da desestatização de bancos públicos.

Retoma-se, nesse ponto, o disposto no art. 52 da Constituição de 1988, o qual estabelece, em seu inciso VI, a competência privativa do Senado para fixar, por proposta do Presidente da República, limites globais para o montante da dívida consolidada da União, dos Estados, do Distrito Federal e dos Municípios. Por sua vez, o inciso IX do mesmo art. 52 atribui ao Senado a competência para instituir limites globais e condições para o montante da dívida mobiliária dos Estados, do Distrito Federal e dos Municípios.

6 MENDES, Marcos. O Senado Federal e o controle do endividamento de estados e municípios. Revista de Informação Legislativa. Brasília, a. 47, n. 187, p. 173-180, jul./set. 2010. p. 173.

7 MENDES, Marcos. O Senado Federal e o controle do endividamento de estados e municípios. Revista de Informação Legislativa. Brasília, a. 47, n. 187, p. 173-180, jul./set. 2010. p. 175.

8 A esse respeito, vide a Lei n. 9.496/1997, que federalizou a dívida dos Estados. 
Marcos Mendes alude à existência de contradição entre o estabelecido no art. 52 da Constituição e a dicção do art. 30 da Lei Complementar n. 101/2000, nos seguintes termos:

Enquanto a primeira, em seu art. 52, estipula como competência privativa do Senado o estabelecimento de limites e condições de endividamento para estados e municípios, a segunda fixa, em seu art. 30, que o Presidente da República submeterá ao Senado uma proposta de limites para o endividamento de estados e municípios. Salvo melhor juízo, a LRF está usurpando a iniciativa do Senado para propor os limites, repassando-a ao Poder Executivo. ${ }^{9}$

Veja-se que a LRF, no seu art. 30, inciso I, estipula que o Presidente da República deverá submeter ao Senado proposta de limites globais para o montante da dívida consolidada da União, dos Estados e dos Municípios, em cumprimento ao art. 52, VI, da Constituição, bem como de limites e condições relativos aos incisos VII (operações de crédito interno e externo), VIII (concessão de garantia da União em operações de crédito interno e externo) e IX (dívida mobiliária dos Estados, Distrito Federal e Municípios), todos do mesmo artigo. Ainda de acordo com o art. 30, inciso II, da LRF, cumpre ao Presidente da República submeter ao Congresso Nacional projeto de lei que estabeleça limites para o montante da dívida mobiliária federal.

Uma controvérsia reside no fato de que a Constituição somente dispõe sobre a submissão da proposta legislativa pelo Presidente da República ao Senado no caso da fixação dos limites globais para o montante da dívida consolidada da União, dos Estados, do Distrito Federal e dos Municípios. Em relação às hipóteses dos incisos VII (limites globais e condições para operações de crédito interno e externo), VIII (limites e condições para a concessão de garantia da União em operações de crédito interno e externo) e IX (limites globais e condições para a dívida mobiliária de Estados, Distrito Federal e Municípios) do art. 52, a competência do Senado é plena e prescinde de proposta do Presidente da República.

Há, contudo, uma outra forma de interpretar a questão. O art. 163, II, da Constituição estabelece que lei complementar disporá sobre a dívida pública externa e interna, incluída a das autarquias, fundações e demais entidades controladas pelo Poder Público. Entendendo-se que a lei complementar de que trata o referido art. 163 é a LRF, em interpretação sistemática, cumpre a esse diploma normativo dispor sobre endividamento, o que faz ao fixar as condicionantes do

9 MENDES, Marcos. O Senado Federal e o controle do endividamento de estados e municípios. Revista de Informação Legislativa. Brasília, a. 47 n. 187, p. 173-180, jul./set. 2010. p. 179. 
art. 30, entre as quais a submissão, pelo Presidente da República ao Senado Federal, de proposta de limites globais e condições relativas ao montante da dívida mobiliária dos Estados, do Distrito Federal e dos Municípios, além das hipóteses dos incisos VI, VII e VIII do art. 52 da Constituição. Não haveria, portanto, que se falar em contradição.

Para além da questão da existência de contradição entre a Constituição e a LRF, no que toca à fixação de limites ao endividamento público, Régis Fernandes de Oliveira aponta para o fato de que, até os dias atuais, o Presidente da República não enviou ao Senado Federal qualquer proposta de estabelecimento dos limites para o endividamento da União. No caso dos Estados, do Distrito Federal e dos Municípios, o autor realça a vigência da Resolução n. 40/2001, do Senado, que dispõe sobre os limites globais para o montante da dívida pública consolidada e da dívida pública mobiliária dos Estados, do Distrito Federal e dos Municípios, e da Resolução n. 43/2001, também do Senado, que trata das operações de crédito interno e externo dos Estados, do Distrito Federal e dos Municípios, inclusive da concessão de garantia. ${ }^{10}$

Para Estados e Distrito Federal, a dívida consolidada líquida deve corresponder a duas vezes as respectivas receitas correntes líquidas, limite cujo atingimento foi previsto para o final do décimo quinto exercício financeiro contado a partir do encerramento do ano da publicação da Resolução n. 40/2001. Para os Municípios, o limite é de 1,2 vez a receita corrente líquida. Para a União, não há a fixação de limite nesses termos.

O diagnóstico de descalabro é esclarecido pelo seguinte entendimento de Élida Graziane Pinto, que, por sua pertinência, merece reprodução na íntegra:

Se se levar em conta apenas a temática do controle do endividamento público, perceber-se-á que falta regulamentação e essa espécie de "ausência seletiva" de regulamentação - porquanto referida apenas aos limites que regeriam a dívida pública do governo federal - tanto é inconstitucional, como causadora de absurda falta de transparência. ${ }^{11}$

Para se ter uma ideia da relevância do tema, a Lei Orçamentária Anual da União referente ao exercício de 2018 previu cerca 1,16 trilhão para refinanciamento da dívida pública federal, o que representa $32,37 \%$ de toda a despesa

10 OLIVEIRA, Regis Fernandes de. Curso de direito financeiro. 7. ed. rev. atual. e ampl. São Paulo: Editora Revista dos Tribunais, 2015. p. 1022.

11 PINTO, Élida Graziane. Financiamento de direitos fundamentais: políticas públicas vinculadas, estabilização monetária e conflito distributivo no orçamento da União do pós-Plano Real. Belo Horizonte: Editora O Lutador, 2010. p. 322-323. 
prevista para o ano de 2018 e, assim, eleva "a gestão da dívida pública à condição de tema de central interesse para a sustentabilidade das contas públicas que, como tal, deve ser objeto de frequentes controles". ${ }^{12}$

Outros dados evidenciam o alcance da questão: de acordo com o Banco Central, em novembro de 2017, o saldo da Dívida Bruta do Governo Geral (DBGG) era de R\$ 4,85 trilhões, ${ }^{13}$ correspondendo a 74,4\% do Produto Interno Bruto (PIB) nacional. Por sua vez, a Dívida Líquida do Setor Público (DLSP) era de 3,33 trilhões, ${ }^{14}$ equivalente a $51,1 \%$ do PIB. ${ }^{15}$

A ausência da fixação de limites para o endividamento da União revela paradoxal lacuna normativa no implemento da própria ideia de gestão fiscal responsável que informa a Lei Complementar n. 101/2000, já que, em relação a outros temas da lei, há um claro detalhamento de procedimentos e controles, como no caso da renúncia de receita, das despesas obrigatórias de caráter continuado e dos gastos com pessoal. ${ }^{16}$

Exsurge, nesse cenário, a importância de um controle mais efetivo da dívida pública federal, vistos seu montante exacerbado e a ausência de limites legais a

${ }^{12}$ MOUTINHO, Donato Volkers; LOCHAGIN, Gabriel Loretto. Controle da gestão da dívida pública federal. Revista do Mestrado em Direito da Universidade Católica de Brasília, Brasília, v. 11, n. 2, p. 45-82, jul-dez. 2017. p. 47. Disponível em: <https://portalrevistas.ucb.br/index.php/rvmd/issue/view/512>. Acesso em: 6 jul. 2018.

13 A chamada Dívida Bruta do Governo Geral engloba o total dos débitos de responsabilidade do governo federal, dos governos estaduais e dos governos municipais, assumidas junto ao setor privado, ao setor público financeiro e ao mercado internacional. BRASIL. Banco Central do Brasil. Dívida bruta do governo geral (\% PIB) - Metodologia utilizada a partir de 2008. Disponível em: <https://dadosabertos.bcb.gov.br/dataset/13762-divida-bruta-do-governo-geral--pib---metodologia-utilizada-a-partir-de-2008>. Acesso em: 9 jul. 2018.

14 O termo "setor público" corresponde às Administrações Diretas e Indiretas dos três níveis de governo (federal, estadual e municipal), incluídas as empresas estatais não financeiras (excetuando-se os grupos Petrobras e Eletrobras) e o sistema público de previdência social. BRASIL. Banco Central do Brasil. Dívida bruta do governo geral (\% PIB) - Metodologia utilizada a partir de 2008. Disponível em: <https://dadosabertos.bcb.gov.br/dataset/13762-divida-bruta-do-governo-geral--pib---metodologia-utilizada-a-partir-de-2008>. Acesso em: 9 jul. 2018.

15 MOUTINHO, Donato Volkers; LOCHAGIN, Gabriel Loretto. Controle da gestão da dívida pública federal. Revista do Mestrado em Direito da Universidade Católica de Brasília, Brasília, v. 11, n. 2, p. 45-82, jul-dez. 2017. p. 48. Disponível em: <https://portalrevistas.ucb.br/index.php/rvmd/issue/view/512>. Acesso em: 6 jul. 2018.

16 PINTO, Élida Graziane. Financiamento de direitos fundamentais: políticas públicas vinculadas, estabilização monetária e conflito distributivo no orçamento da União do pós-Plano Real. Belo Horizonte: Editora O Lutador, 2010. p. 320. 
constrangê-la, com nefastas resultantes para as contas públicas nacionais e a provisão de serviços públicos eficientes à coletividade, o que causa o contingenciamento de recursos necessários à efetivação de políticas públicas, como nos alerta Élida Pinto:

Sem lidar com limites normativos para o montante total da dívida, para a meta de resultado nominal e, assim, indiretamente para o custeio do serviço da dívida, a União tem convivido, desde 1994, com o notório avanço da dívida pública, não obstante tal política significar o "sacrifício" de todas as demais ações governamentais previstas na lei orçamentária anual. ${ }^{17}$

Importante destacar que a carência de regulamentação atinge outro ponto importante da LRF, que é aquele atinente ao Conselho de Gestão Fiscal (art. 67). Esse órgão, ainda não implementado, passadas quase duas décadas da promulgação da lei, é a face mais nefasta do federalismo à brasileira. Responsável pelo acompanhamento e pela avaliação, de forma permanente, da política e da operacionalidade da gestão fiscal, visando a, entre outras finalidades, disseminar práticas que resultem em maior eficiência na alocação e na execução do gasto público, na arrecadação de receitas, no controle do endividamento e na transparência da gestão fiscal, carece de criação legal, sendo suprimida a importante participação dos demais entes federativos na condução das finanças nacionais. Órgão federal hoje exerce tal papel, qual seja, a Secretaria do Tesouro Nacional, com a preponderância dos interesses da União. Nos termos da lei, o Conselho seria formado por representantes de todos os Poderes e esferas de governo, do Ministério Público e de entidades técnicas representativas da sociedade. Atualmente, tramitam na Câmara dos Deputados o Projeto de Lei 3.744/2000, que institui o Conselho de Gestão Fiscal e dispõe sobre sua composição e forma de funcionamento, e o Projeto de Lei Complementar n. 210/2015, com origem no Senado, que regulamenta o art. 67 da LRF, ampliando as atribuições do Conselho de Gestão Fiscal. ${ }^{18}$

A não instituição do Conselho, até o momento, é um dos fatores que agravam a percepção generalizada de descontrole das contas públicas. Sua implementação, mais do que nunca, se faz urgente, haja vista as consequências deletérias que o desequilíbrio fiscal vem provocando sobre a capacidade de investimento do gover-

17 PINTO, Élida Graziane. Financiamento de direitos fundamentais: políticas públicas vinculadas, estabilização monetária e conflito distributivo no orçamento da União do pós-Plano Real. Belo Horizonte: Editora O Lutador, 2010. p. 328.

18 BRASIL. Câmara dos Deputados. Câmara analisa projeto que altera critérios de composição do Conselho de Gestão Fiscal. 2016. Disponível em: <http://www2.camara.leg.br>. Acesso em: 9 jul. 2018. 
no e, em um efeito cascata, sobre a própria capacidade de recuperação da atividade econômica no país, que busca se recuperar no atual período de crise sistêmica.

É, portanto, de suma importância que a dívida pública seja controlada com austeridade e responsabilidade pelos gestores públicos e devidamente fiscalizada pelos órgãos de controle, não apenas pelo seu montante, que é excessivo, como também por suas repercussões intergeracionais: é preciso evitar que a irresponsabilidade da geração presente no manuseio dos recursos públicos se torne um peso insustentável para as gerações vindouras.

\section{REGRAS SOBRE A DÍVIDA PÚBLICA NA LEI DE RESPONSABILIDADE FISCAL}

Como já mencionado, as definições, diretrizes e prescrições da LRF sobre o endividamento do Estado estão presentes em seus arts. 29 a 33. São elas, em linhas gerais: 1) O Senado, por proposta do Presidente, estabelece os limites de endividamento; 2) Se a dívida ultrapassar o limite imposto pelo Senado, deverá ser reconduzida ao limite dentro de três quadrimestres; 3) Enquanto perdurar o excesso, fica proibida a contratação de nova operação de crédito; 4) Vencido o prazo para o retorno da dívida ao limite, e perdurando o excesso, cessam as transferências voluntárias; 5) $\mathrm{O}$ ente da federação deve encaminhar ao Ministério da Fazenda pedido de autorização para contratar operação de crédito; 6) A operação de crédito contratada junto a instituição financeira que esteja em desacordo com a LRF será considerada nula, devendo ser cancelada, com a devolução do principal e a proibição do pagamento de juros e encargos. ${ }^{19}$

Os limites de endividamento são estabelecidos em relação à receita corrente líquida dos entes: 2 vezes a RCL para Estados e 1,2 vez para os Municípios, realizando-se, a cada quadrimestre, a verificação do seu atendimento. Quando o ente extrapola o limite estabelecido para o endividamento ao final de um quadrimestre, a ele deve retornar até o término dos três quadrimestres subsequentes, além de ter que reduzir o excedente em pelo menos $25 \%$ já no primeiro quadrimestre subsequente àquele em que foi ultrapassado o limite (art. 31, LRF).

Vale lembrar, além disso, que há outros montantes e procedimentos que, direta ou indiretamente, geram dívida pública. A esse respeito, Ana Carla Bliacheriene e Renato Brown Ribeiro, após apontarem os avanços promovidos pela

19 KHAIR, Amir; AFONSO, José Roberto R.; OLIVEIRA, Weder de. Lei de Responsabilidade Fiscal: os avanços e aperfeiçoamentos necessários. In: MENDES, Marcos (Coord.). Gasto público eficiente: propostas para o desenvolvimento do Brasil. Rio de Janeiro: Topbooks Editora, 2006. p. 304. 
LRF no controle do endividamento público, indicam questões críticas passíveis de maior atenção, especialmente por parte dos gestores públicos:

Não obstante o franco progresso, há uma série de aspectos da dívida que ainda não são controlados como: os restos a pagar; o afrouxamento da disciplina fiscal da União; pouca transparência na relação entre política fiscal e monetária e pressões sobre o equilíbrio entre as autorizações orçamentárias e o fluxo financeiro que ainda representam dúvidas e problemas que devem ser acompanhados e discutidos, principalmente no que se refere ao orçamento federal..$^{20}$

Os restos a pagar são dívidas contraídas perante fornecedores e prestadores de serviço ao Estado, as quais são originadas de despesas empenhadas e não pagas, independentemente de sua liquidação, incluindo-se parcelas das dívidas assumidas em face de instituições financeiras empenhadas e não pagas em seu vencimento.

Segundo a LRF (art. 42), é vedado ao gestor público contrair, nos dois últimos quadrimestres de seu mandato, obrigação de despesa que não possa ser cumprida integralmente dentro dele ou que tenha parcelas a serem pagas no exercício seguinte sem que haja suficiente disponibilidade de caixa para esse fim. Devido à divergência de interpretações das Cortes de Contas, já se admitiu que despesas anteriores aos dois quadrimestres finais do mandato fossem inscritas sem a devida cobertura financeira, onerando a disponibilidade financeira na execução do

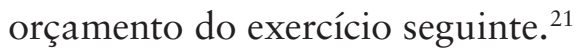

No que tange à União, a metodologia de apuração das disponibilidades financeiras transferidas de um exercício a outro e a forma de cálculo do superávit primário influenciaram na geração de um "orçamento paralelo", em que o montante de restos a pagar aumentou mais de sete vezes no período compreendido entre os anos de 2003 e 2010, partindo de R $\$ 18$ bilhões e atingindo o patamar de R 128 bilhões. Na verdade, como bem destacam Ana Carla Bliacheriene e Renato Brown Ribeiro, esse movimento acabou por engendrar uma plurianualidade nas autorizações orçamentárias em descompasso com o quadro normativo das finanças públicas fixado na Constituição da República de $1988 .{ }^{22}$

20 BLIACHERIENE, Ana Carla; RIBEIRO, Renato Jorge Brown. A questão do endividamento público dez anos após a publicação da Lei de Responsabilidade Fiscal: avanços e limitações. Revista de Informação Legislativa, Brasília, a. 49, n. 194, p. 159-172, abr./jun. 2012 . p. 167.

21 BLIACHERIENE, Ana Carla; RIBEIRO, Renato Jorge Brown. A questão do endividamento público dez anos após a publicação da Lei de Responsabilidade Fiscal: avanços e limitações. Revista de Informação Legislativa, Brasília, a. 49, n. 194, p. 159-172, abr./jun. 2012 . p. 167.

22 BLIACHERIENE, Ana Carla; RIBEIRO, Renato Jorge Brown. A questão do endividamento público dez anos após a publicação da Lei de Responsabilidade Fiscal: avanços e limitações. Revista de Informação Legislativa, Brasília, a. 49, n. 194, p. 159-172, abr./jun. 2012. p. 167. 
O uso sistemático do endividamento como instrumento da política econômica vem extrapolando a visão clássica da dívida pública como meio de atender às necessidades de financiamento do setor público, visando a prover bens e serviços públicos. No Brasil, após o Plano Real, com o avanço dos esforços para estabilização da economia, a dívida pública passou a ser empregada como meio de incrementar ou reduzir a liquidez monetária, independentemente do uso de instrumentos tradicionais, como a taxa básica de juros ou o encaixe bancário. ${ }^{23}$ Salienta-se que esses procedimentos não são neutros e produzem custos fiscais, o que é agravado pelo fato de tais valores não serem de amplo conhecimento da sociedade, dada a sua opacidade. ${ }^{24}$

\section{DÍVIDA PÚBLICA E POLÍTICA ECONÔMICA: OS DESAFIOS DA REALIDADE BRASILEIRA}

Em uma perspectiva keynesiana, a política fiscal assume papel contracíclico, sendo empregada para atenuar recessões ou superaquecimentos na economia, em circunstâncias nas quais a dívida se torna uma ferramenta da política econômica. Essa abordagem recebe críticas, pois, de acordo com estudiosos de outros vieses da economia, o financiamento do gasto público por meio do aumento da dívida gera ineficiência alocativa, redundando em déficits orçamentários que, por sua vez, provocam a ineficácia da própria política fiscal anticíclica. ${ }^{25}$

Sob o ponto de vista da política, a ausência de previsão de limites para a dívida pública da União vai ao encontro da necessidade de regulamentação menos densa e mais flexível na seara econômica, o que ocorre, infelizmente, em descompasso com a concretização das normas constitucionais sobre endividamento público.

23 De acordo com o Banco Central do Brasil, encaixe se refere ao provisionamento de recursos, pelas instituições bancárias, visando a fazer frente às necessidades de movimentação financeira. BRASIL. Banco Central do Brasil. Recolhimentos compulsórios, encaixe e direcionamentos obrigatórios. Disponível em: <https://www.bcb.gov.br/htms/novaPaginaSPB/compulsorios. asp>. Acesso em: 23 jul. 2018.

${ }^{24}$ BLIACHERIENE, Ana Carla; RIBEIRO, Renato Jorge Brown. A questão do endividamento público dez anos após a publicação da Lei de Responsabilidade Fiscal: avanços e limitações. Revista de Informação Legislativa, Brasília, a. 49, n. 194, p. 159-172, abr./jun. 2012. p. 169.

${ }^{25}$ CALDEIRA, Alessandro Aurélio; MOREIRA, Tito Belchior Silva; SERRANO, André Luiz Marques; WILBERT, Marcelo Driemeyer. Sustentabilidade da dívida estadual brasileira: uma análise da relação dívida líquida e resultado primário. Revista de Administração Pública, Rio de Janeiro, v. 50, n. 2, p. 285-306, mar./abr., 2016. Disponível em: <http://www.scielo.br/pdf/ rap/v50n2/0034-7612-rap-50-02-00285.pdf>. Acesso em: 12 jul. 2018. p. 288. 
De fato, ao tratar da utilização da dívida pública como instrumento da política econômica desde meados dos anos 1990, Élida Graziane Pinto evidencia a falta de neutralidade, a qual perpassa governos de diferentes matizes ideológicos:

Fato é que, em torno da administração da dívida pública brasileira, restaram erigidos alguns pressupostos inquestionáveis (como o são o superávit primário e o custeio do serviço da dívida), por mais que estivessem sendo afetadas diversas outras ações governamentais e o próprio desenvolvimento econômico no período considerado. ${ }^{26}$

Em resumo, embora o regramento dos arts. 29 a 33 da LRF se destine à aplicação a todos os entes federativos, a falta de normas regulamentadoras específicas acerca dos limites para o endividamento da União compromete a plena eficácia desses dispositivos. É como se o dever de gerir responsavelmente as finanças públicas recaísse, efetivamente, apenas sobre os entes subnacionais, a despeito de todo o quadro constitucional-legislativo em vigor. ${ }^{27}$ Saliente-se que a mora legislativa da União não é sanada pelo propalado Teto dos Gastos Públicos (Emenda Constitucional n. 95/2016), já que esse marco normativo de viés excepcional e transitório visa a controlar a expansão da despesa primária federal, que, por natureza, não inclui a dívida pública aqui tratada.

$\mathrm{O}$ quadro narrado de déficit de regulamentação compromete a gestão fiscal responsável e revela um problema fundamental que transcende o direito. Como bem observado por Amir Khair, José Roberto R. Afonso e Weder de Oliveira, persiste no Brasil um grave descompasso entre a evolução qualitativa das normas que regem as finanças públicas, o processo orçamentário e a gestão fiscal, de um lado, e, por outro, a capacidade administrativa e, principalmente, a vontade e determinação política de nossos Poderes e instituições (Poderes Executivo, Legislativo e Judiciário, Ministério Público e Tribunais de Contas) para operacionalizar tal evolução. ${ }^{28}$ Por mais paradoxal que possa parecer tal afirmação neste momen-

26 PINTO, Élida Graziane. Financiamento de direitos fundamentais: políticas públicas vinculadas, estabilização monetária e conflito distributivo no orçamento da União do pós-Plano Real. Belo Horizonte: Editora O Lutador, 2010. p. 327.

27 Em que pese a carência de regulamentação, destaca-se que tanto a Lei n. 1.079/1950, que define os crimes de responsabilidade cometidos pelo Presidente da República, pelos Ministros de Estado, pelos Ministros do Supremo Tribunal Federal e pelo Procurador-Geral da República, quanto o Decreto-Lei n. 201/1967, que tipifica os crimes de responsabilidade praticados por prefeitos e vereadores, proíbem que o gestor ultrapasse os limites de endividamento, penalizando-o pela não recondução do montante da dívida aos limites legais.

${ }^{28}$ KHAIR, Amir; AFONSO, José Roberto R.; OLIVEIRA, Weder de. Lei de Responsabilidade Fiscal: os avanços e aperfeiçoamentos necessários. In: MENDES, Marcos (Coord.). Gasto pú- 
to, é possível sustentar que não faltam normas, inclusive normas de boa qualidade, apesar das pontuais e importantes lacunas; o que falta é, antes de tudo, vontade e capacidade para efetivar as diretrizes normativas já em vigor.

Chama a atenção, por exemplo, o fato de que se previu inicialmente no projeto de lei de diretrizes orçamentárias da União para o ano de 2018 a tão aguardada auditoria da dívida pública, a ser realizada com a participação de entidades da sociedade civil, no âmbito do Ministério da Fazenda e do Banco Central. No entanto, tal dispositivo foi vetado pelo Presidente da República, ao argumento de que a Constituição, em seu art. 71, confere ao Tribunal de Contas da União a competência para realizar a auditoria externa nas contas públicas, incluindo a dívida pública federal, o que, nos termos do veto, "ocorre regularmente". Ainda, de acordo com as razões do veto presidencial, o controle externo das contas públicas é apoiado pelo Sistema de Controle Interno, o qual realiza auditorias internas por meio da Controladoria-Geral da União (atual Ministério da Transparência e Controladoria-Geral da União), o que reforçaria o monitoramento. Além disso, nos termos do veto, a auditoria pretendida, diante do conceito de dívida pública, que abrange obrigações do conjunto do setor público não financeiro, englobando os entes político-administrativos e as respectivas Administrações Direta e Indireta, poderia acarretar a violação do pacto federativo, além de ocasionar um elevado custo para a União. ${ }^{29}$

\section{DA INTERFACE ENTRE PLANEJAMENTO ESTATAL, METAS FISCAIS E DÍVIDA PÚBLICA}

Diante dessa conjuntura, as críticas até aqui tecidas acerca do descontrole da dívida pública federal ficam realçadas, uma vez que não faltam iniciativas visando ao estabelecimento de um marco normativo mais denso sobre os limites a serem observados pela União, e sim a vontade política de torná-los efetivos, haja vista a necessidade de contrariar consensos erigidos não só sobre o manuseio e controle das contas públicas, como também sobre o planejamento e direcionamento da política macroeconômica nacional.

Frisa-se, nesse ponto, que a Lei de Diretrizes Orçamentárias, prevista no art. 165 da Constituição de 1988, ao lado das demais leis orçamentárias - Plano

blico eficiente: propostas para o desenvolvimento do Brasil. Rio de Janeiro: Topbooks Editora, 2006. p. 317.

29 BRASIL. Secretaria Legislativa do Congresso Nacional. Estudo do veto n. 25/2017. 2017. Disponível em: <http://legis.senado.leg.br/sdleg-getter/documento?dm=7334285\&disposition=inli ne>. Acesso em: 11 jul. 2018. 
Plurianual e Lei Orçamentária Anual -, deve tratar das metas e prioridades da Administração Pública, incluindo as despesas de capital para o exercício financeiro subsequente, bem como dispor sobre as alterações na legislação tributária, além de estabelecer a política de aplicação das agências financeiras oficiais de fomento.

Em linhas gerais, pode-se compreender que é função da Lei de Diretrizes Orçamentárias detalhar as disposições do Plano Plurianual para cada exercício financeiro e, assim, guiar a elaboração da Lei Orçamentária Anual, estabelecendo metas e prioridades para a Administração Pública para o exercício financeiro seguinte. Trata-se de instrumento cuja finalidade é operacionalizar e materializar a interface entre o PPA e a LOA, ${ }^{30}$ tendo em vista o disposto na Constituição de 1988 .

O modelo de planejamento delineado na Constituição de 1988 mostrou-se inefetivo, uma vez que a concepção constitucional das três leis orçamentárias não tem funcionado na prática do governo, notadamente nos entes subnacionais, devido, entre outros fatores, "à disfuncionalidade regulamentar que elas experimentam no âmbito infraconstitucional, em face da leniência para a efetividade por parte dos gestores e órgãos de controle". ${ }^{31}$

Por essa razão, propusemos a adoção de modelo alternativo, ao qual denominamos "Orçamento Biopolítico Zero" - cuja origem remonta à prática orçamentária utilizada nos Estados Unidos -, em que se rompe a concepção meramente incremental de gastos de um exercício para outro, visando à manutenção das estruturas estatais, muitas vezes obsoletas ou inertes. A ideia é a de que se avalie, anualmente, a necessidade de manutenção ou de supressão dos desembolsos do Estado vinculados a determinados programas, projetos ou atividades. ${ }^{32}$

Com efeito, dentro da noção de planejamento, não há como negar que a situação das finanças públicas impacta não só o orçamento como também a própria estrutura administrativa e de gestão do Estado. A eficiência governamental

30 CARDOSO JR., José Celso; GIMENEZ, Denis Maracci. Crescimento econômico e planejamento no Brasil (2003-2010): evidências e possibilidades do ciclo recente. In: CARDOSO JR., José Celso (Org.). A reinvenção do planejamento governamental no Brasil. Brasília: Ipea, 2011. p. 337-429.

31 MOURÃO DE OLIVEIRA, Licurgo Joseph. Orçamento público biopolítico: corrupção, transparência e efetivação dos gastos. 2016. 631f. Tese (Doutorado em Direito) - Faculdade de Direito, Universidade de São Paulo, São Paulo, 2016. p. 291.

32 MOURÃO DE OLIVEIRA, Licurgo Joseph. Orçamento público biopolítico: corrupção, transparência e efetivação dos gastos. 2016. 631f. Tese (Doutorado em Direito) - Faculdade de Direito, Universidade de São Paulo, São Paulo, 2016. p. 308-309. 
serve não só ao propósito de reduzir gastos, influenciando, também, na quantidade de recursos à disposição do Estado e de seus cidadãos. ${ }^{33}$

Diante do panorama de crise econômica e fiscal que ora se faz presente, é essencial que o Estado promova a transparência dos atos de governo e de gestão dos administradores públicos, de forma a aferir se os gastos públicos atingiram com eficiência os efeitos esperados e, assim, se foram concretizadas as políticas públicas em execução. Impõe-se, portanto, avaliação crítica e periódica acerca da permanência dos programas governamentais, de modo a escapar da lógica incremental, em que os aportes orçamentais aumentam de exercício em exercício, sem que se saiba ao certo se os resultados previstos foram alcançados. ${ }^{34}$

Veja-se, por outro lado, que, para garantir o cumprimento das metas fiscais, em atendimento às previsões dos arts. $8^{\circ}, 9^{\circ}$ e 13 da LRF, a Administração Pública deverá fazer a programação orçamentária e financeira da execução das despesas públicas, bem como o monitoramento do cumprimento das metas de superávit primário.

Com efeito, a Lei de Responsabilidade Fiscal ressalta a importância do resultado primário para o controle do endividamento público. Resultado primário é, basicamente, a diferença entre receitas e despesas governamentais, excluindo-se os montantes referentes aos encargos da dívida, aí incluídas as parcelas de amortização e juros. Esse resultado reflete o esforço fiscal do período considerado, bem como a variação da dívida líquida. ${ }^{35}$ Assim, se o governo gasta menos do que arrecada, desconsiderada a apropriação dos juros sobre a dívida líquida existente, há superávit primário, resultado que pode contribuir para a redução dos passivos, a elevação dos ativos, ou a combinação de ambas.

Como já mencionado anteriormente, se a dívida consolidada do ente da federação ultrapassar o limite fixado ao final de um quadrimestre, deverá ser a ele reconduzida até o fim dos três quadrimestres subsequentes, reduzindo-se o exce-

33 CALDEIRA, Alessandro Aurélio; MOREIRA, Tito Belchior Silva; SERRANO, André Luiz Marques; WILBERT, Marcelo Driemeyer. Sustentabilidade da dívida estadual brasileira: uma análise da relação dívida líquida e resultado primário. Revista de Administração Pública, Rio de Janeiro, v. 50, n. 2, p. 285-306, mar./abr. 2016. Disponível em: <http://www.scielo.br/pdf/ rap/v50n2/0034-7612-rap-50-02-00285.pdf>. Acesso em: 12 jul. 2018. p. 286.

${ }^{34}$ MOURÃO DE OLIVEIRA, Licurgo Joseph. Orçamento público biopolítico: corrupção, transparência e efetivação dos gastos. 2016. 631f. Tese (Doutorado em Direito) - Faculdade de Direito, Universidade de São Paulo, São Paulo, 2016. p. 289.

35 BRASIL. Secretaria do Tesouro Nacional. Manual de estatísticas fiscais do Boletim Resultado do Tesouro Nacional. 2016. Disponível em: <http://www.tesouro.fazenda.gov.br>. Acesso em: 12 jul. 2018. 
dente, já no primeiro quadrimestre, em 25\%. Para alcançar novamente o equilíbrio, o ente deverá obter superávit primário.

Nesse sentido, tanto o superávit primário (resultado positivo da diferença entre receitas e despesas governamentais, excluído o pagamento de juros) quanto o déficit primário (resultado negativo) são empregados como indicadores da consistência entre as metas de políticas macroeconômicas e a sustentabilidade da dívida pública. Nessa perspectiva, o resultado primário evidencia a capacidade de o governo honrar os compromissos firmados, já que sua formação serve ao propósito de garantir recursos para pagar os encargos da dívida pública e reduzir o endividamento a médio e longo prazos. ${ }^{36}$

A exigência de metas de sustentabilidade da dívida pública tem precedentes no histórico legislativo brasileiro recente. Em meados da década de 90 do século passado, a crise da dívida dos Estados culminou na repactuação firmada entre esses entes subnacionais e a União, o que foi formalizado por meio da Lei n. 9.496/1997. Por meio do Programa de Reestruturação e de Ajuste Fiscal, foram previstos metas ou compromissos relativos à dívida consolidada, ao resultado primário, às despesas com pessoal, às receitas de arrecadação própria, à gestão pública e às disponibilidades de caixa.

Esse contexto de ajuste com vistas à gestão fiscal sustentável culminou na edição, no ano 2000, da Lei de Responsabilidade Fiscal, que passou a exigir com ênfase uma nova postura dos gestores públicos no que tange a, entre outros tópicos relevantes, endividamento público, buscando como princípio a disciplina no manuseio dos recursos públicos e a melhora na credibilidade dos entes em face das dívidas assumidas.

De fato, nos termos do art. $8^{\circ}, \mathbb{2 ^ { \circ }}$, da LRF, não serão objeto de limitação as despesas que constituam obrigações constitucionais e legais do ente, incluindo aquelas destinadas ao pagamento do serviço da dívida, e as ressalvadas pela Lei de Diretrizes Orçamentárias. É clara a posição de prioridade ocupada pelo pagamento do serviço da dívida, que é excetuado dos limites incidentes sobre a execução do orçamento.

Ainda de acordo com a LRF ( $\operatorname{art} .9^{\circ}$, caput), se for verificado, ao final de um bimestre, que a realização da receita poderá não comportar o cumprimento das metas de resultado primário ou nominal estabelecidas no Anexo de Metas Fiscais, os Poderes (Legislativo, Executivo e Judiciário) e o Ministério Público promoverão, por ato próprio e nos montantes necessários, nos trinta dias subse-

36 BRASIL. Senado Federal. Superávit primário. Disponível em: <https://www12.senado.leg.br/ noticias/entenda-o-assunto/superavit>. Acesso em: 23 jul. 2018. 
quentes, limitação de empenho e movimentação financeira, conforme critérios estabelecidos pela Lei de Diretrizes Orçamentárias.

O Supremo Tribunal Federal já se manifestou em caráter liminar sobre a possibilidade de o Poder Executivo limitar valores financeiros dos Poderes Legislativo e Judiciário e do Ministério Público quando estes não promoverem a limitação no prazo fixado no caput do art. $9^{\circ}$ : de acordo com o voto do Ministro Ilmar Galvão na ADI 2238, julgada em 9/8/2007, a previsão do art. $9^{\circ}, \$^{\circ}$, da LRF contém hipótese de interferência indevida do Poder Executivo nos demais Poderes e no Ministério Público. Em outras palavras, entendeu-se que a imposição do Poder Executivo nessas circunstâncias viola a independência e a harmonia entre os Poderes preconizada pelo art. $2^{\circ}$ da Constituição.

O entendimento do STF vai ao encontro do que consigna o ordenamento constitucional, já que assegura a autonomia financeira dos demais poderes, do Ministério Público, dos Tribunais de Contas e da Defensoria Pública, em face da ingerência do Poder Executivo, o qual não pode alterar os valores constantes das respectivas propostas orçamentárias que estejam em conformidade com a LDO.

\section{NOTAS SOBRE O PROJETO DE LEI COMPLEMENTAR PARA A LIMITAÇÃO DA DÍVIDA PÚBLICA DA UNIÃO}

Preservando-se a independência entre os poderes, busca-se o equilíbrio orçamentário, dentro de uma tônica de limitação do endividamento público, de promoção da transparência orçamentária e de controle de gastos do Estado, visando à sustentabilidade das contas públicas.

Por essa razão, no que tange ao endividamento público, no momento da aprovação do orçamento anual, vale a chamada "regra de ouro", segundo a qual as operações de crédito não podem superar o montante das despesas de capital inicialmente fixadas, ressalvadas, já quando iniciada a execução orçamentária, as operações realizadas mediante créditos suplementares ou especiais com finalidade precisa (Constituição de 1988, art. 167, inciso III). Essa regra visa a coibir que o endividamento público seja utilizado para a manutenção da máquina administrativa e para a realização de outros serviços ordinários, em vez de ser empregada em sua finalidade precípua, que é a de propiciar investimentos.

Ainda em relação ao estabelecimento de limites para a dívida, atualmente, tramita na Câmara dos Deputados o Projeto de Lei Complementar n. 41/2011, que altera a LRF para estabelecer limites ao pagamento da dívida pública, condicionando a sua assunção à realização da auditoria prevista no art. 26 do Ato das 
Disposições Constitucionais Transitórias - a qual, diga-se de passagem, nunca foi efetivada. ${ }^{37}$

O projeto não só veda a realização da dívida pública até que seja efetuado o exame analítico e pericial dos fatos geradores do endividamento, conforme preconiza o art. 26 do ADCT, como também estabelece que a dívida pública, em cada período de apuração e em cada ente da federação, não poderá exceder $5 \%$ da receita corrente líquida.

Observe-se que o limite proposto é significativamente mais restritivo do que aquele previsto, hoje, na Resolução n. 40/2001, para Estados e Municípios. Como justificativa para tamanha constrição, foram apresentados dados sobre o montante superlativo da dívida, que alcançou o patamar de $36 \%$ do orçamento geral da União em 2011, as altas taxas de juros praticadas na economia brasileira e a própria ausência de limites para o endividamento no âmbito federal, que propicia terreno fértil para a especulação.

Não se pretende examinar o mérito da proposta, em especial pela ausência, na justificativa, de dados específicos que subsidiem a fixação do percentual máximo diminuto $(5 \%)$ para a dívida pública dos entes federativos em relação às respectivas receitas correntes líquidas. Reconhece-se, no entanto, a importância de iniciativas que visam a estabelecer parâmetros claros para a realização da dívida pública, embora não seja recomendável, sob pena de engessamento e desconsideração das diferentes realidades regionais, que se imponha um só teto para o endividamento dos distintos entes político-administrativos, nos três níveis da federação.

Diante de todas as considerações tecidas, o tema "dívida pública" emerge como um dos tópicos centrais da agenda política e econômica nacional, demandando o suprimento imediato de importantes lacunas legislativas, principalmente no que tange ao estabelecimento de limites para a dívida da União, que atualmente carece de parâmetros, ao contrário do que ocorre com os demais entes federativos.

$\mathrm{O}$ verdadeiro imperativo de responsabilidade fiscal deve espraiar-se desde o planejamento até a execução, passando pela normatização acerca das finanças

\footnotetext{
37 Art. 26. No prazo de um ano a contar da promulgação da Constituição, o Congresso Nacional promoverá, através de Comissão mista, exame analítico e pericial dos atos e fatos geradores do endividamento externo brasileiro.

$\mathbb{S} 1^{\circ}$ A Comissão terá a força legal de Comissão parlamentar de inquérito para os fins de requisição e convocação, e atuará com o auxílio do Tribunal de Contas da União.

$\mathbb{S} 2^{\circ}$ Apurada irregularidade, o Congresso Nacional proporá ao Poder Executivo a declaração de nulidade do ato e encaminhará o processo ao Ministério Público Federal, que formalizará, no prazo de sessenta dias, a ação cabível.
} 
públicas, sem que seja possível deixar de contemplar um ou alguns entes em detrimento de todos os demais, principalmente em uma nação como o Brasil, que, ao menos na perspectiva do direito positivo, apregoa o federalismo de cooperação, no texto de sua Lei Maior.

A atual crise política, econômica e social exige seriedade e responsabilidade no manuseio das contas públicas, além do efetivo controle.

\section{REFERÊNCIAS}

BALEEIRO, Aliomar. Uma introdução à ciência das finanças. 19. ed. revista e atualizada por Hugo de Brito Machado Segundo. Rio de Janeiro: Forense, 2015. BLIACHERIENE, Ana Carla; RIBEIRO, Renato Jorge Brown. A questão do endividamento público dez anos após a publicação da Lei de Responsabilidade Fiscal: avanços e limitações. Revista de Informação Legislativa, Brasília, a. 49, n. 194, p. 159-172, abr. / jun. 2012.

BRASIL. Banco Central do Brasil. Dívida bruta do governo geral (\% PIB) Metodologia utilizada a partir de 2008. Disponível em: <https://dadosabertos.bcb.gov. br/dataset/13762-divida-bruta-do-governo-geral-pib-metodologia-utilizada-a-partirde-2008>. Acesso em: 9 jul. 2018.

BRASIL. Banco Central do Brasil. Recolhimentos compulsórios, encaixe e direcionamentos obrigatórios. Disponível em: <https://www.bcb.gov.br/htms/ novaPaginaSPB/compulsorios.asp >. Acesso em: 23 jul. 2018.

BRASIL. Câmara dos Deputados. Câmara analisa projeto que altera critérios de composição do Conselho de Gestão Fiscal. 2016. Disponível em: <http://www2. camara.leg.br>. Acesso em: 9 jul. 2018.

BRASIL. Secretaria do Tesouro Nacional. Manual de estatísticas fiscais do Boletim Resultado do Tesouro Nacional. 2016. Disponível em: <http://www.tesouro.fazenda. gov.br>. Acesso em: 12 jul. 2018.

BRASIL. Secretaria Legislativa do Congresso Nacional. Estudo do veto n. 25/2017. 2017. Disponível em: <http://legis.senado.leg.br/sdleg-getter/documento?dm=7334285\& disposition=inline>. Acesso em: 11 jul. 2018.

BRASIL. Senado Federal. Superávit primário. Disponível em: <https://www12.senado. leg.br/noticias/entenda-o-assunto/superavit>. Acesso em: 23 jul. 2018.

CALDEIRA, Alessandro Aurélio; MOREIRA, Tito Belchior Silva; SERRANO, André Luiz Marques; WILBERT, Marcelo Driemeyer. Sustentabilidade da dívida estadual brasileira: uma análise da relação dívida líquida e resultado primário. Revista de Administração Pública, Rio de Janeiro, v. 50, n. 2, p. 285-306, mar. / abr. 2016. Disponível em: <http://www.scielo.br/pdf/rap/v50n2/0034-7612-rap-50-02-00285. pdf $>$. Acesso em: 12 jul. 2018. 
CARDOSO JR., José Celso; GIMENEZ, Denis Maracci. Crescimento econômico e planejamento no Brasil (2003-2010): evidências e possibilidades do ciclo recente. In: CARDOSO JR., José Celso (Org.). A reinvenção do planejamento governamental no Brasil. Brasília: Ipea, 2011.

KHAIR, Amir; AFONSO, José Roberto R.; OLIVEIRA, Weder de. Lei de Responsabilidade Fiscal: os avanços e aperfeiçoamentos necessários. In: MENDES, Marcos (Coord.). Gasto público eficiente: propostas para o desenvolvimento do Brasil. Rio de Janeiro: Topbooks Editora, 2006.

MENDES, Marcos. O Senado Federal e o controle do endividamento de estados e municípios. Revista de Informação Legislativa, Brasília, a. 47, n. 187, p. 173-180, jul. / set. 2010.

MOURÃO DE OLIVEIRA, Licurgo Joseph. Orçamento público biopolítico: corrupção, transparência e efetivação dos gastos. 2016. 631f. Tese (Doutorado em Direito) - Faculdade de Direito, Universidade de São Paulo, São Paulo, 2016.

MOUTINHO, Donato Volkers; LOCHAGIN, Gabriel Loretto. Controle da gestão da dívida pública federal. Revista do Mestrado em Direito da Universidade Católica de Brasília, Brasília, v. 11, n. 2, p. 45-82, jul-dez. 2017. Disponível em: <https:// portalrevistas.ucb.br/index.php/rvmd/issue/view/512>. Acesso em: 6 jul. 2018.

OLIVEIRA, Regis Fernandes de. Curso de direito financeiro. 7. ed. rev. atual. e ampl. São Paulo: Editora Revista dos Tribunais, 2015.

PINTO, Élida Graziane. Financiamento de direitos fundamentais: políticas públicas vinculadas, estabilização monetária e conflito distributivo no orçamento da União do pós-Plano Real. Belo Horizonte: Editora O Lutador, 2010. 